\title{
РЕЦЕНЗИИ
}

UDC 327

\section{A glorious history of international studies in Russia ${ }^{\star}$}

\author{
D. A. Lanko
}

St. Petersburg State University,

7-9, Universitetskaya nab., St. Petersburg, 199034, Russian Federation

For citation: Lanko D. A. A glorious history of international studies in Russia. Vestnik of Saint Petersburg University. International Relations, 2019, vol. 12, issue 4, pp. 531-536.

https://doi.org/10.21638/11701/spbu06.2019.409

Many people, especially in, but not limited to Europe, tend to believe that if something is good, it must have a long history. There are various implications of this assumption across social sciences and humanities. In democracy studies, for example, the assumption has produced the debate on the differences between "old" and "new" democracies, many participants of which have arrived in conclusion that old democracies are more stable, while new democracies are more fragile [1]. Representatives of far-right movements in various European countries, including in Russia and some other new independent states, who are predominantly proponents of primordial theory of nationalism [2], are engaged in debates with each other about whose nation is "older" assuming that "older" nations are also "better", despite both the "conclusion" and the "logic" behind it seem absurd to me.

Closer to international relations, in 2003 the assumption became the primary reason for many Europeans not to buy then US Defense Secretary Donald Rumsfeld's argument that "old" European countries are outdated in their refusal to support US policy in Iraq, while Europe must "renew" in the way demonstrated by "new" European countries, which predominantly supported the Iraq war [3]. Back then and today, most people in "new" European countries want their countries to become "older", and most people in "old" European countries do not want their countries to become "younger".

Awareness of this assumption is an important prerequisite to reading of MGIMO (Moscow State Institute of International Relations University) Professor Marina Lebedeva's "Russian Studies of IR". Lebedeva rightly points that very few Russian scholars in the field of international studies doubt that "the Westphalian system with its ideas of sover-

* [Review:] Lebedeva M. M. Russian Studies of International Relations: From the Soviet Past to the PostCold-War Present. Stuttgart, ibidem-Verlag, 2018. 224 p.

(C) Санкт-Петербургский государственный университет, 2019 
eignty" (p. 20) forms the basic layer of contemporary system of international relations. Most Russian scholars agree that the Westphalian system has dominated this world for over 370 years, while the debate on a possible crisis of the Westphalian system that was characteristic of Western international relations literature around $350^{\text {th }}$ anniversary of the Westphalian Treaties [4] has been hardly noticed by Russian scholars.

Neither could the assumption help influencing Russian debate on globalization, which began with the publication of Lebedeva's (co-authored by Andrey Melville, currently Professor at Moscow's Higher School of Economics) article in 1999 [5]. More than half of books on globalization published in Russia since then mention that globalization has not only been an important trend in international relations since 1970s, but that a trend with the same name played an important role in international relations in late $19^{\text {th }}-$ early $20^{\text {th }}$ century, too. Authors of those books assume, though sometimes unconsciously, that globalization's at least century-long history will convince contemporary readers to take globalization more seriously than they could have if they thought of globalization as of a recent phenomenon.

Lebedeva evaluates the state of international studies in Russia as good. Russian universities are homes to over a dozen of faculties and to many dozens of departments, which have "international relations" in the name. Hundreds of scholars work for the faculties and departments as well as for a number of research institutes, both within the system of the Russian Academy of Sciences and outside of it, including a handful of non-profits active in international studies. Multiple academic journals are being published in both Russian and English languages. Altogether, those scholars have a great potential: though Lebedeva admits that "Russian scholars [have not yet created] a 'great idea' in the field of IR studies" (p. 55), she does not doubt that the "great idea" is coming. One reason to believe in the good current state of international studies in Russia is the "glorious history" of the discipline, which, according to Lebedeva, did not emerge in 1990s on the ruins of the Soviet Union, but which is deeply rooted in international studies of the Soviet era.

There are at least two reasons for me to recommend the book to Russian scholars in the field of international studies, to their foreign colleagues, and to students both in Russia and abroad. First, this is a very personal book. In the introduction, Lebedeva herself states that she is "offering [her] vision of the development of international studies in Russia, limited by [her] experience, communication with colleagues, and the processes that [she] observed" (p. 13). Even the language of the book reflects its personality. Predominantly, Russian (and not only Russian) scholars use a more sophisticated, so-called academic language, when writing books and articles, and they use a more "mundane" language, when making presentations at conferences or when lecturing. In reading this book, however, immediately come memories of Marina Lebedeva's speaking at various conferences that I have had the pleasure to attend.

An important part of Lebedeva's personal road to prominence in Russian international studies was connected to her research in international negotiations undertaken in 1980s and 1990s. Liberal paradigm of international relations could not help influencing that research. In her book, Lebedeva underlines the role of Robert Putnam's "two-level game" model [6] as a game-changer in negotiations studies (p. 50), though she humbly forgets to mention that she was the first to introduce the model to a wide audience of Russian scholars in international studies after collapse of the Soviet Union, thus laying the ground 
for a new direction of conflict studies. That direction has never become a mainstream in negotiations studies in Russia, however.

According to Lebedeva, in Russian international studies, less «attention is paid to the technology of negotiation and conflict resolution, [but more attention is paid to] the factors that generate conflict» (p. 58). At the same time, her own early research belongs to the studies "carried out in the liberal tradition, particularly concerning issues on negotiation...", in her own words (p. 56). While not being part of the mainstream herself, Lebedeva observes the mainstream of international studies in Russia from a distance, thus making her volume extremely valuable to those, who would like to find out, how "realism has become... the predominant theoretical approach in Russian IR studies" (p. 101).

Realism came to replace Marxism-Leninism as the predominant theoretical approach in Russian international studies after collapse of the Soviet Union. That replacement did not happen overnight, but realism and Marxism-Leninism co-existed in Soviet international studies during the Cold War. Lebedeva does not write much about the role of Nikolay Inozemtsev, long-time Director of the Institute of World Economy and International Relations (currently named after Russian prominent diplomat Yevgeny Primakov) of the Soviet (currently Russian) Academy of Sciences, in encouraging Soviet scholars to introduce some realist concepts into their research of international relations, but that happened mostly due to Inozemtsev's death, which occurred shortly after Lebedeva arrived in the field of international studies. However, she could not help making a reference to at least one of his late edited volumes on global challenges [7].

The versions of Marxism-Leninism and realism that competed for the minds of Soviet scholars of international relations throughout most part of the Cold War era were not exactly the versions of Marxism and realism that contemporary scholars are used to. To describe Soviet scholars' realist leaning in those times, Lebedeva uses the term "intuitive realism", which "was not related to theoretical studies of classical realism" (p. 39). In other words, many Soviet scholars of the Cold War era became realists without having read Morgenthau's book [8] first. Later on, when they read the book and learned about its impact on international studies in the West, it only convinced them that their intuition did not fail.

Soviet scholars applied only a limited version of Marxism-Leninism in their research conducted during the Cold War, and Lebedeva's book reflects it very well. Soviet scholars widely discussed early $20^{\text {th }}$ century Lenin's concept of "withering away of the state" (p. 28) as a result of transition from capitalism and imperialism to socialism and further to communism, and they became critical to that idea half-a-century later, when they observed that despite transition to socialism in a number of countries had occurred, it did not reduce the role of states in international relations. However, they neglected Lenin's idea of foreign policy as a continuation of domestic politics, which could have formed the basis for liberal-oriented foreign policy analysis to emerge in Russia after collapse of the Soviet Union, despite Soviet-era "Diplomatic Dictionary" [9] defined foreign policy as a continuation of domestic politics.

Similarly, Soviet scholars knew a lot about the heritage of Leo Trotsky, first Foreign Minister (People's Commissioner of Foreign Affairs) of the newly founded Bolshevik state, mostly about his concept of "permanent revolution" (p. 28). However, they had little knowledge about the heritage of Maxim Litvinov, Trotsky's successor as Soviet Foreign Minister in 1930s, including about his concept of "equal and indivisible peace", which 
recently transformed into the concept of "equal and indivisible security", one of the key concept of Russian foreign policy doctrine since 2013 [10; 11]. Western realists are better familiar with Litvinov's concept thanks to Edward Carr, who criticized it as a form of "scientific ineptitude" [12, p. 13], than their Russian colleagues. Despite Litvinov's intellectual heritage plays an important role in contemporary Russian foreign policy-making, very little research has been done on the concept of "equal and indivisible security" in Russia; thus, it is not surprising that one will not find mentions of either Litvinov or the concept in Lebedeva's book.

Lenin once suggested that Marxism had three sources (classical German philosophy, English political economy and French utopian socialism) and three parts (materialist philosophy, economic theory of added value and social theory of class struggle). By the Cold War times, however, Marxism-Leninism had appeared to consist of only two parts: the concept of the only true theory, which is "omnipotent because right" and the "only true" theory itself. That concerned all branches of social sciences and humanities, thus providing the ground for Russia’s former Prime Minister Yegor Gaydar and current Rector of RANEPA (Russian Presidential Academy of National Economy and Public Administration) Vladimir Mau to argue that Marxism-Leninism was a kind of "civilian religion" [13].

With Marxism-Leninism playing the role of the "only true" theory in the Soviet Union, realist-leaning Soviet scholars in international relations had to pretend being Marxists though applying concepts of realism to their analysis of international politics. After collapse of the Soviet Union, they came out as realists. Moreover, some of them declared realism the new "only true" theory. They either neglected other theoretical orientations or declared them kinds of realism. For example, though the most known book by Graham Allison in Russia is his "Essence of Decision" [14], Russian realists believe that Allison was a realist, too, because his many other works were devoted to nuclear parity between the great powers. This is the environment, in which non-realists work in contemporary Russia. Lebedeva's book has to be praised for making Russian non-realists sound.

Another reason, why I would recommend this book to faculty members and students in particular, is that this book observes teaching of international relations as an integral part of international studies in Russia. Unification of teaching and research is another change that occurred together with the collapse of the Soviet Union. In the Soviet Union, teaching and research in the field of international studies were separated. Research was predominantly concentrated in Moscow, in the Academy of Sciences, though MGIMO had its own researchers, while teaching was predominantly concentrated in universities and institutes, such as MGIMO, though some researchers of the Academy of Sciences simultaneously taught students outside of the Academy's premises. Outside of Moscow, students had very few options to major in international relations; one of the available options mentioned in Lebedeva's book was located in Kyiv, contemporary Ukraine (p. 77). However, the book does not tell about research outcomes of those, who taught international relations in Kyiv in the Cold War times, because little is known about it.

In Post-Cold-War Russia, the division between teaching and research in the field of international studies has become vague. The share of researchers of the Academy of Sciences simultaneously involved in teaching has significantly increased compared to the Cold War era. Also, and more importantly, most faculty members teaching international relations have been engaged in research. Most Russian universities today use science met- 
rics as the major tool of evaluation of faculty members. Though Lebedeva admits that it has caused some problems, she at the same time praises it as "stimulus for the intensification of scientific research, including in the field of international relations in Russia" (p. 67). The situation, when faculty members teaching international relations in Russian universities, likewise their Western colleagues, have to "publish or perish", is the first challenge to teaching of the discipline in contemporary Russia.

Another challenge is privatization of international relations. In Russian universities, it appears in two forms. First, it is what Lebedeva refers to as "commercialization" (p. 87) of higher education in the field of international relations in Russia. Outside of Moscow and St. Petersburg, faculties and departments of international relations at various Russian universities are heavily dependent on income from tuition. Second, it is the tendency not mentioned in Lebedeva's book, when fewer graduates majoring in international relations find jobs in diplomatic service in particular and in public administration in general, but more of them find jobs in private companies and non-profits. That tendency pushes Russian universities to change curricula and, given than most faculty members are simultaneously involved in research, research programs.

Globalization of international relations is a challenge, too. Again, globalization influences faculty members of Russian universities, who teach and conduct research in international relations, in two ways. First, international research teams undertake most sound research projects in the field of international studies (likewise in most disciplines, both sciences and humanities), not national or one-university research teams. According to Lebedeva, that challenges integrity of Russian research space, because scholars working for universities in the European part of Russia tend to cooperate with colleagues from European universities, while scholars from universities located in Siberia and Russian Far East tend to cooperate with colleagues from the Asia-Pacific Region (p. 90).

Second, the share of international students majoring in international relations, who come to study in Russian universities, has been constantly growing since the collapse of the Soviet Union. That forces Russian scholars teaching international relations to change the focus of their lectures and seminars. In the Cold War era, most students majoring in international relations were expected to become Soviet diplomats, intelligence officers or trade representatives. In contemporary Russia, students majoring in international relations, even those who aim at becoming a diplomat, an intelligence officer or a trade representative upon graduation, do not necessarily aim at becoming a Russian diplomat, intelligence officer or trade representative, simply because not all of them are Russian nationals. Time will demonstrate how Russian scholars teaching international relations will manage to accommodate that change into their curricula and research programs.

International studies in Russia develop faster than editors manage to process books about them. It was only one year ago, when Lebedeva wrote, "in Russian academic literature on international relations there have been almost no studies on compatriots" (p. 158). Also, one will not find anything in Lebedeva's book about scholars from the Baltic Federal University named after Immanuel Kant, most frequently quoted contemporary Russiaborn scholar in the world, located in Kaliningrad, who publish in the field of international studies. Today, one has to admit that the Baltic Federal University has managed to create a sound group of scholars in the field of international studies, and that studies of the role that Russian compatriots play in international relations are developing thanks, though not exclusively, to them. This is only one example of recent development of international stud- 
ies in Russia growing on the ground of their glorious history, to which Lebedeva's book is devoted.

\section{References}

1. Maeda, K. (2016), Honeymoon or Consolidation, or Both? Time Dependence of Democratic Durability. Democratization, vol. 23, no. 4, pp. 575-591, doi: 10.1080/13510347.2014.989387.

2. Coakley, J. (2018), 'Primordialism' in Nationalism Studies: Theory or Ideology? Nations and Nationalism, vol. 24, no. 2, pp. 327-347, doi: 10.1111/nana.12349.

3. Grote, I. (2007), Donald Rumsfeld's Old and New Europe and the United States' Strategy to Destabilize the European Union. Rivista di Studi Politici Internazionali: Nuova Serie, vol. 74, no. 3 (295), pp. 347-356.

4. Cutler, A.C. (2001), Critical Reflections on the Westphalian Assumptions of International Law and Organization: A Crisis of Legitimacy. Review of International Studies, vol. 27, no. 2, pp. 133-150.

5. Lebedeva, M. M., Melville, A. Y. (1999), Transitional Age' of Contemporary World. Mezhdunarodnaia zhizn', no. 10, pp. 76-84. (In Russian)

6. Putnam, R. D. (1988), Diplomacy and Domestic Policy: The Logic of Two-Level Game. International Organization, vol. 42, no. 3, pp. 427-460.

7. Global Contemporary Challenges, (1981), ed. by N. N. Inozemtsev. Mysl' Publ., Moscow, 285 p. (In Russian)

8. Morgenthau, H. (1948), Politics among Nations: The Struggle for Power and Peace. Alfred A. Knopf, New York, XVI+489+XX p.

9. Diplomatic Dictionary, in 3 vols., (1971), ed. by A.A. Gromyko et al. Politizdat Publ., Moscow, $612+592+749$ pp. (In Russian)

10. Foreign Policy Concept of the Russian Federation. Approved by President of the Russian Federation Vladimir Putin on February 12, 2013, available at: https://www.voltairenet.org/article202037.html (accessed: 25.08.2019).

11. Foreign Policy Concept of the Russian Federation. Approved by President of the Russian Federation Vladimir Putin on November 30, 2016, available at: http://www.mid.ru/en/foreign_policy/official_documents/-/asset_publisher/CptICkB6BZ29/content/id/2542248 (accessed: 25.08.2019).

12. Carr, E. H. (2016), The Twenty Years' Crisis, 1919-1939; reissued with a new preface from Michael Cox. London, Palgrave Macmillan. 233 p.

13. Gaydar, E. T., Mau, V. A. (2004), Marxism: Between Scientific Theory and Civilian Religion. Voprosy ekonomiki, no. 5, pp. 4-27. (In Russian)

14. Allision, G. (1971), Essence of Decision: Explaining the Cuban Missile Crisis. Boston, Little, Brown and Company, $338 \mathrm{p}$.

Received: September 10, 2019

Accepted: October 3, 2019

Author's information:

Dmitry A.Lanko — PhD, Associate Professor; d.lanko@spbu.ru 